\title{
歯髄の電気刺激による頭皮上誘発電位に対する針麻酔の効果
}

藤本 洋

\section{Effect of acupuncture on scalp potential evoked by electric tooth pulp stimulation}

\author{
Hiroshi FUjмото
}

\section{I. 緒言}

針麻醉は1958年，中国での成功が 報告されて以来 ${ }^{1,2)}$ 世界各国で数多くの追試報告がなされており，著者ら も, 口腔外科領域の手術 ${ }^{3}$, 疼痛治療 4 なとと針麻醉を 応用し，ある程度効果があることを認めた。針が鎮痛効 果を有することは古くから経験的に知られていたにもか かわらず，その医学的評侕は低かった。しかし，中国で の針麻酷の成功が大きく報道されてから，針麻酔は副作 用が少なく, 痛覚のみをほぼ選択的に, しかも容易に抑 制するとして注目を集めた。しかし，その効果は不安定 で，科学的衰付けが十分ではなく，作用機序解明につい ても，各方面でょうやくその緒に付いたところである. そこで著者は，歯䯣に発する感覚は人ではもっぱら痟覚 であるといわれているのに注目し、これを研究に利用す ることを考えた。

人の歯牙に，強い電気刺激を与兄，その結果中枢神経 内に惹起される主要な電位変動は痛みに四連したもので ある可能性が強い，そこで通常の脳波を記録する方法で 頭皮上より誘発電位を得ることができれば，痛みに対す る針麻醖の效果を客観的に定量化するためのよい指標と なると思われるので実験を行った。

\section{II. 実 験 方 法}

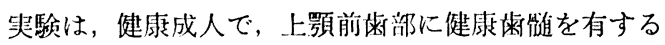
成人男子 41 名，無铕歯を有する成人男子 3 名を対象とし た.

刺激電極は刺激電流を掬蹃に限局させうるように同一

需知学院大学函学部第 2 口腔外科学教空（主任：河 合 幹教授)

Second Department of Oro-maxillo-facial Surgery, School of Dentistry, Aichigakuin University (Chief:

Prof. Tsyuoshi Kawai)

受付日：昭和53年 2 月14日
前歯歯冠の唇侧および舌側に置いた。この電極は直径 3 〜 $4 \mathrm{~mm}$ で米の表面に電極糊とともに貼付けし, あらか じめ作製して扣いたセルロイドシーネで歯列全体を打拉 らように被覆して電極を固定した。電極抵抗は 30〜70 $\mathrm{k} \Omega$ であった。な扣刺激電流が雪肉へ滑走しないよう に, 唾夜の侵入を防ぐためのラバーダム防湿を施した (図 1).

被験者は, シールドルーム内で閉眼, 安静に仰臥させ た。電気刺激は, 被験者の耐之うる最大強度の $0.1 \mathrm{msec}$

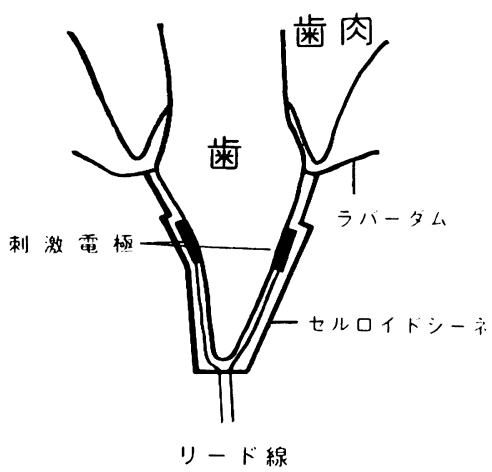

図 1 唯に刺激電極を装着固定する方法を示す圀

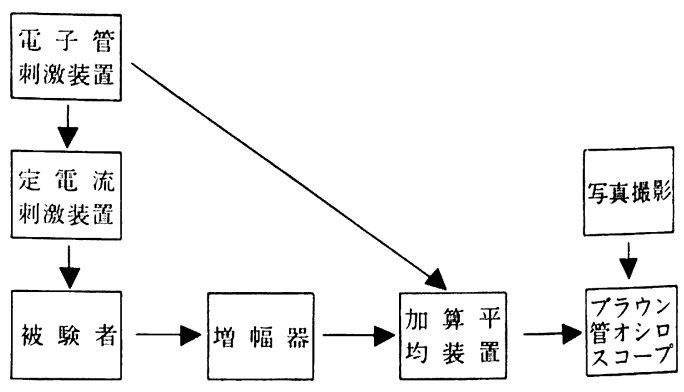

図 2 夹臥のブロック・ダイフグラム

留子管刺激装置より被検者に刺激を与えると同時 に，加算平均装風を掃引させるよ5にした。 
の矩形波を，電子管刺激装置（日本光電裂 SEN-110 型） を用いて与古, 痛み刺湤とした。この時の電流量は 3.3 $\sim 8.8 \mathrm{~mA}$ (平均 $5.02 \mathrm{~mA}$ ) であった。

誘発電位導出のためには, 脳波用針電㥛（または銀皿 電極) を用い, 拈もに単極 (時に双極) 誘䆃し, 増幅器 (日本光電製 Multipurpose Polygraph RM 150 型),

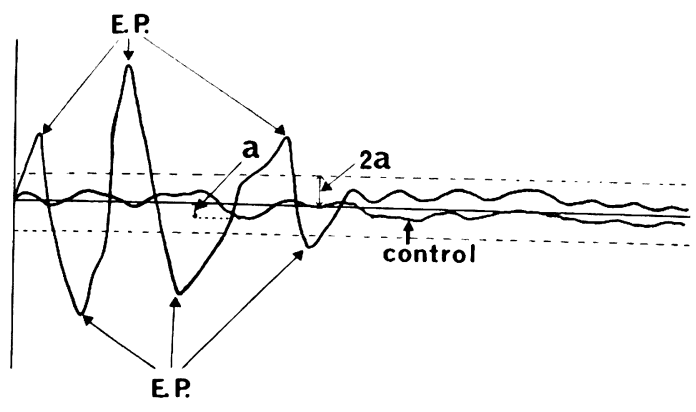

図 3 誘発電位を分析する力法を示す怅 点線は無刺激時の背景脳波を200回加算した時の 振幅を 2 倍したものでこの点線より大きな電位変動 を, 䄧発電位 (E.P.) とした。
加算平均装笽（日本光電幣 ATAC 501-10 型）を用い て, 200 回加算平均を行い，ブラウン管オシロスコープ に得られた没形を写真撮影した（図2）。

このよらにして得られた電位変動の波形を, 図了のご とく, 無刺激時の背景脳波を200 回加算平均した波形の 最大振幅の（a）を2 倍した幅（2a）を基線を中心にし て上下にとり，これより大きな電位変動を誘発電位 ( $\mathrm{E}$. P.) とした（図了）。得られた誘発電位については潜時・ 振幅について分析を行った.

誘発電位が得られた被験者13名47試行に針麻酔を行っ た。針麻酔の方法は，刺激歯牙と同側の商面の経穴 3 か 所（四白・人中・迎香）および反対側の合谷・三間に針 刺し, 中国製針麻酔器 6-27-7 型および BT-701 型を参 考にした自家製針麻酔器を用い， $7 \sim 10 \mathrm{~V}, \quad 2 \sim 3 \mathrm{~Hz}$ で通電した。

さらに，針麻酔による自覚的な痛覚閾值の変化と，誘 発電位の相関を調べるため, 被験者 5 名に, 歯(陽極)・ 口唇 (陰極) で電気刺激を加光, 針麻酔経過中の痛覚間 値の変化を，歯䯣診断器 (Malk 製 Dentotest) を用い て测定し, 誘発電位との関係について検討した。

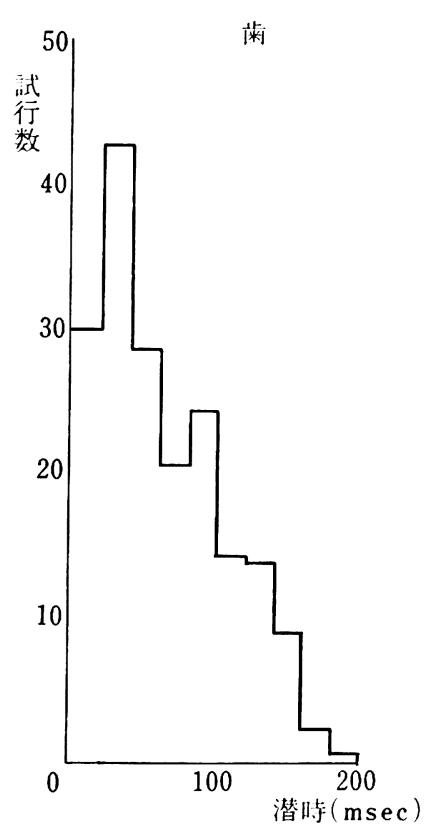

[a]

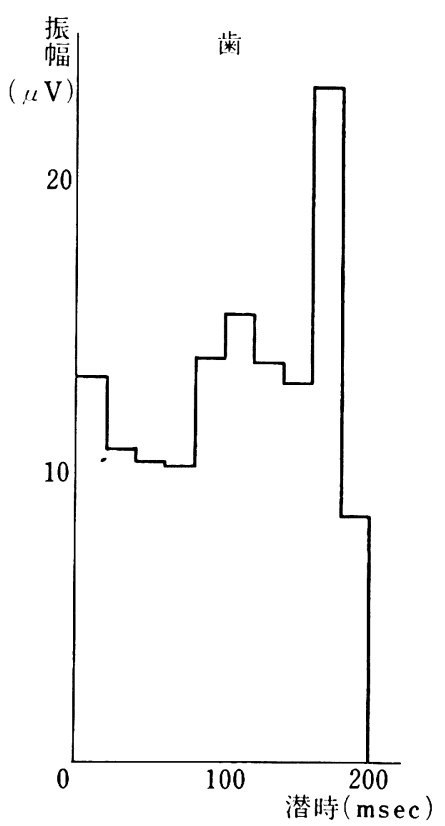

[b]

図 4 读の電気刺激による頭皮上誘発電位の出現頻度とその振幅を 示す闵

図a：出現頻度を表わし, 横軸は潜時, 縱軸は試行数を表 わす.

図 b：振幅を表わし，横軸は潜時, 綻斬は試行数を表わす。 


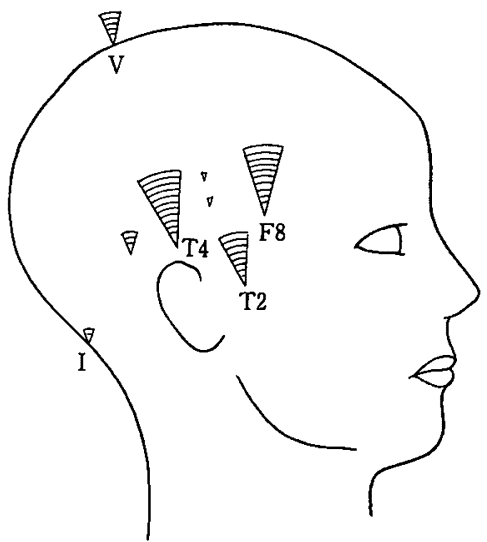

反対側

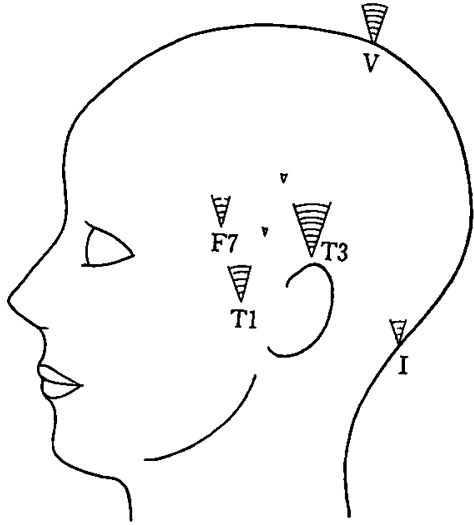

同側

図 5 頭皮上誘発電位の遵出部位を示す図

䅪層円錐は誘発電位の出現頻度を示す（ $V$ の線 1 本が 2 個）同 側, 反対側は刺激部位と記録部位の関係を示す。 $\mathrm{T}_{1}, \mathrm{~T}_{2}$ は Silver$\operatorname{man}^{6)}$ による。その他は10-20方式5よる。

\section{III. 実 験 結 果}

\section{1. 頭皮上誘発電位について}

頭皮上誘発電位は，被験者44名について 154 試行中 36 名99試行で得られた。 得られた誘発電位の頂点潜時は, 10〜193 msec の範囲であったが，20〜40 msec である ことが最も多く，潜時の長いものほど出現頻度が滇時減 少した（図 4 の a).

振幅は $10.2 〜 23.4 \mu \mathrm{V}$ であったが，潜時 $80 \mathrm{msec}$ ま でのものは比較的小さく，それより長潜時のるの，特 に 160〜180 msec のものは大きな振幅を示した(図 4 の b).

\section{i）頭皮上誘発電位の導出部位}

電極配直については，種々試みた結果，誘発電位が 得られるのは，10-205) 方式の $\mathrm{T}_{3} \cdot \mathrm{T}_{4}, \mathrm{~F}_{7} \cdot \mathrm{F}_{8}$ およ び Silverman による $\left.T_{1}{ }^{6}\right) \cdot T_{2}$ を中心とした部分で あることがわかった，誘発電位は刺激と同側および対 側ともに記録できたが，対側でより多く記録し得た (91:52) (図 5).

ii）頭皮上誘発電位に対する検討

記録した誘発電位が雪䯣以外の感覚入力または顔面 表情筋や頸部の筋などの反射性放電またはそれによる 電極の動摇に由来するかもしれないので，次の 4 点に ついて卧験を行い倹討した。

(a) 歯肉への電流滑走により，歯肉内の感覚神経 が刺激された結果である可能性があるので, 被験者 3 名 3 例について, 誘発電位が得られることを確認した あと，刺激粀牙根尖部に $2 \%$ 塩酸りドカイン $0.5 \mathrm{cc}$ を用いて浸潤麻酙を行ったところ，3例ともに浸潤麻
背景脳波活動の加算平均値

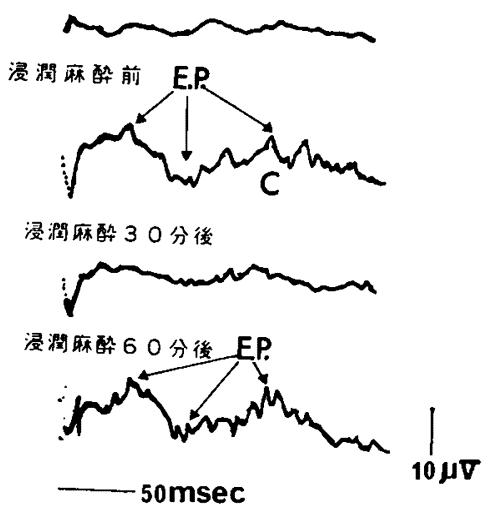

図 6 頭皮上誘発䉓位が得られた被駗 者の刺激海牙の根尖部に $2 \%$ 塩 酸りドカイン $0.5 \mathrm{cc}$ を浸潤麻 酔した時の顽皮上誘発電位の変 化を示す。

醉後15〜30分に誘発笔位に相当寸る電位変化は認めら れず，また，浸㵎栛酔60分後には，3例とも誘発電位 が回復した(図 6). ゆえにこの誘発電位には，歯骾か らの求心性線維が扣もに関与していると考えられる.

（b）齿髄以外の刺激による可能性をさらに明確に 除外するために, 誘発電位が得られた被験者のらち, 無鲢歯を有するもの3名に電気刺激を与えて記録した ところ，3例ともに誘発電位に相当する電位変化は認 められなかった(図 7)，ゆ六に得られた誘発電位は， 
崡周組織刺激によるものではないと考えられる.

（c）痛み刺激に対して反射性に若起された眼球運 動図を記録している可能性，あるいは眼輪筋などの放 電をたは収縮による記録電極の動摇による変化を誘発 電位として誤認している可能性を検討寸るために，被 験者 3 名の眼球周辺に記録電極を置き, 雪に電気刺激 を与えて，その電位変化を記録したところ，3 例とも に誘発電位に相当する電位变化は認められなかった (図 8).ゆえに上記の可能性は否定できるのではない かと考えられる。

(d) 頸部や後頭部の筋の放電またはそれらの収縮 による電極の動摇が原因であるかもしれないので, 後
頭部に置いた電極から電位変化を記録した，前側頭部 で誘発電位が得られた場合には, 後頭部に置いた電極 からも, 振幅は同じ位ではあるが, 潜時の遅い電位変 動が得られることもあった。 しかし，前側頭部では電 位変動は得られなくとも, 後頭部では誘発電位とは似 ていない電位変動が得られる場合があった。ゆえに,

この結果より, 痛みに対する頸の反射運動による可能 性は少ないと考えられる。

\section{2. 頭皮上誘発電位に及ぼす針麻酔の影響}

頭皮上誘発電位が得られた被験者 13 名 47 試行に針麻酔 を行ったところ，被験者11名41試行に針麻酔が有効であ った，針麻酔が有効な場合には，自覚的な痛覚閶値の上

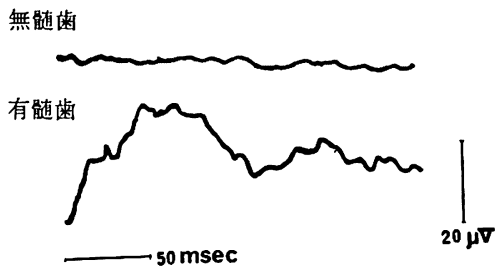

図 7 同一被験者の無噵㽤と有髄菌に 電気刺激を与えた時の電位変動 を示す。

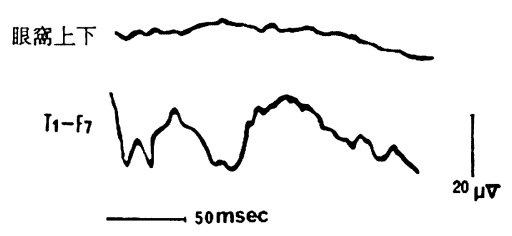

図 8 歯に電気刺湤を与えて, 眼盆の 上下と $\mathrm{T}_{1}-\mathrm{T}_{7}$ に記録電極を置 いて得た電位変動を示す。

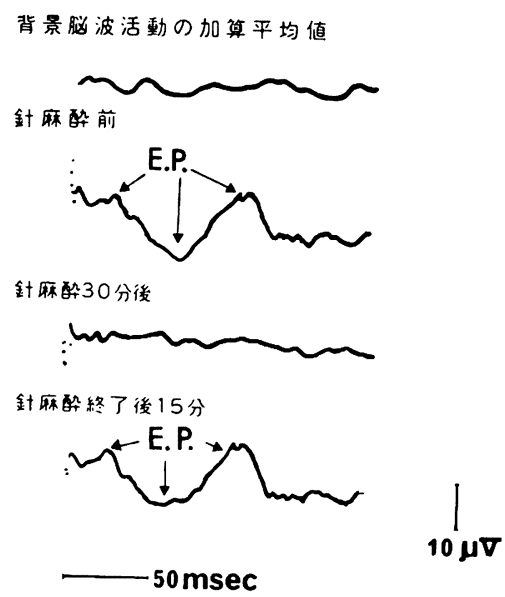

図 9 針麻酔が有効な場合の 200 回加 算した頭皮上誘発電位の変化を 示し, 針麻酔30分後に頭皮上誘 発電位が消失し, 終了後15分で 誘発電位が回復した例。

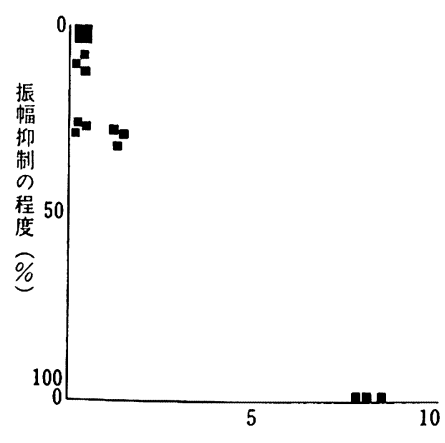

針麻醉15分

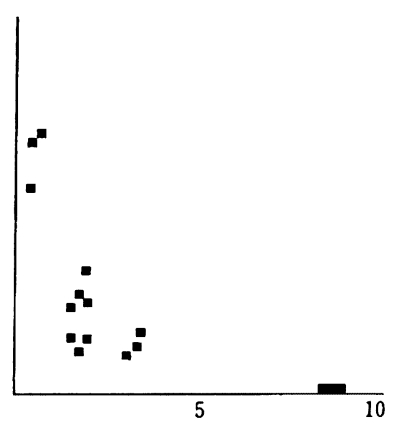

針麻醉 30 分

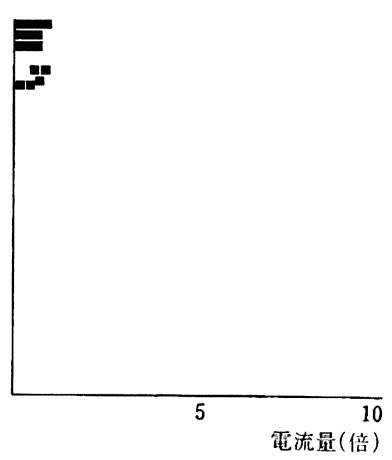

針麻醉後15分

図 10 針麻酔による自覚的痛覚䦭値上昇と頭皮上誘発電位の関係を表わす図で，横軸は，針麻酔 前の痛覚闘值を基準とし, 針麻酔後の痛覚閾値の変化を示し, 艇軸は, 頭皮上誘発電位に対 する針麻酔の抑制の程度を示す。 
抑制の頻度（試行数）

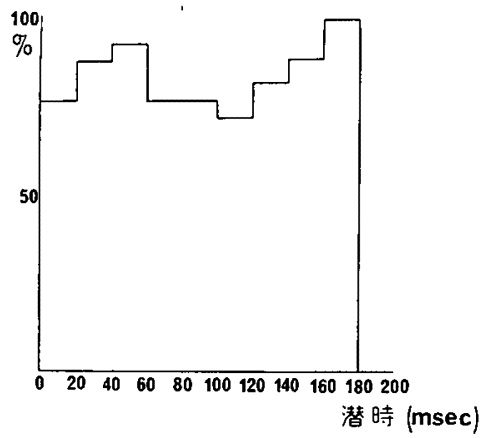

[a]
抑制の程度（振幅）

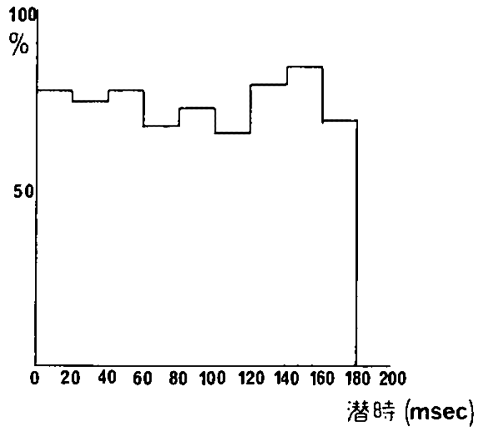

[b]

図 11 針麻酔による頭皮上誘発電位の抑制の頻度怙よび程度を表わす 困で，横軸は潜時，縦軸は\%を表わす。

昇とよく平行して頭皮上誘発電位の消失，または振幅の 低下を認めた（図 9)，図 9 にその1例を示す、針麻酔 開始30分後に自覚的な痛覚闇值の上昇とともに，頭皮上 誘発電位が消失し，針麻酔終了後15分で，頭皮上誘発電 位および自覚的痛覚閥值ともに，針麻酔前とほぼ同様な 水準にまで回復した。

針麻酔による自覚的痛覚闇值の上昇については，全例 とも針麻酔開始 15 分後位より痛覚閏值が $1.2 \sim 6$ 倍上昇 し，1例を除いて針麻酔終了後15分で，痛覚間值が針麻 酔前の值にほぼ回復しているのがみられ，自覚的にも針 麻酔が有効であることが認められた（図 10）。針麻酔に よる痛覚抑制のない人では，頭皮上誘発電位に変化はみ られなかった。

さらに頭皮上誘発電位の振幅が50\%以上抑制され，同 時に自覚的痛覚抑制のあった人で，抑制の発現嚬度と振 幅抑制の程度について検討した。

抑制の発現頻度については，潜時 $160 \sim 180 \mathrm{msec} の$ 誘発電位が抑制されることが最も多かったが，それ以外 の潜時の誘発電位が抑制を受ける機会は72〜93\%とほぼ 均等であった（図 11 の a).

振幅の抑制程度についても，66〜85\%で，抑制の発現 瀕度と同様に，各潜時間に大きな差は認められなかった (図 11 の b).

$$
\text { IV. 考案 }
$$

著者は，本実験が，痛みに対する針麻酔効果の客観的 指標になると考え，実験を行った，その結果，針麻酕に より自覚的な疼痛闖值の上昇とよく平行して頭皮上誘発 電位の振幅の㧕制がみられ，本実験の目的は遂げられ た. しかし，歯牙の刺激方法，頭皮上誘発電位の記録方 法, およびその性質, 針麻酔の生理学的機序等について は十分に吟味しなければならない必要があることがわか
った．以下それらの問題点について考察を加える.

1. 刺激方法について

ヒト歯䯣に電気刺激を与えるためには，被験歯を他の 歯や，周囲組織から隔絶して，刺激電流が漏洩するのを 防止しなければならず，そのためには従来はラバーダム 防湿を行い，排唾管にて唾液を吸引し行っていたが，こ の方法では被験者は開口を強いられ，長時間の実験には 不都合であった。一方, 被験者の被刺激歯牙に窩洞形成 を行い，窩洞内に刺激電極を埋入・固定すれば，刺激電 極としては確実であるが，対象がヒトである場合には， この方法は望ましくない。

そこで本実験では，人体に組織損傷を残すことなく刺 激電極を確実・簡単に装着する方法として，仰卧位では 比較的重液に触れず，また他の歯や周囲組織より隔絶し やすい上䫇前㧘を対象とした，被刺激歯牙を，ラバーダ ム防湿し，その上に，あらかじめ作製しておいたセル口 イドシーネを装着し，刺激電極を固定する方法を用い た.この方法では，被験者は長時間開口を強いられるこ ともなく，また電極の固定も確実で容易であった。

Chatrian 5 ${ }^{8)}$ は電に窩洞形成を行い, 刺激電極を装着 して，刺激電流が歯䯣に限局するようにしている，Matthews ら9) は歯冠の煩舌側に刺激電極を固き，双極で刺 激して扣り，これは齿牙周囲組織や，雪根膜に電流が抎 がるのを防止でき，単極で刺激するよりる，より確実に 歯䯣を刺激できる利点があり，Mumford ら の煩舌側に刺激電極を固いて崡牙を刺激した場合には， その刺激電流は崡冠齿䯣のみを流れることを報告して いる，著者は得られた頭皮上誘発電位が崡骮刺激により 生じたものであることを，無䯣齿と浸潤麻酔を用いた実 験により裹付けた。このことは Chatrian ${ }^{8)}$ あほぼ同様 の結果を報告している. 


\section{2. 歯髄刺激による頭皮上誘発電位の波形について}

ヒトの歯に電気刺激を加え, 頭皮上誘発電位を記録し た報告としては, Spreng ら ${ }^{11)}$, Schmidt ${ }^{12)}$, Chatrianら 13)，佐野 ${ }^{14)}$ がある. Spreng ら ${ }^{11)}$ は潜時 $75 \sim 120 \mathrm{msec}$ に, Schmidt ${ }^{12)}$ は $87.2 \pm 1.9 \mathrm{msec}$ に主要な電位変動を 有すると報告している。一方 Chatrian $5^{13}$ は，頭頂部 で 5 相性の誘発電位を記録し，その頂点潜時は，38，

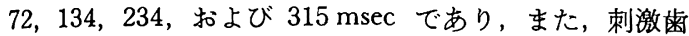
牙と反対側の中心後回下方より，潜時 $75 お$ よび $108 \mathrm{msec}$ の誘発電位を記録したと報告している．佐野 ${ }^{14)}$ も Chatrian ら ${ }^{13)}$ とほぼ同様の結果を報告している.

著者の結果では，潜時 $20 \sim 40 \mathrm{msec}$ の反応が最もよ 〈みられ, $80 \mathrm{msec}$ まで漸時出現頻度が減少し, 80〜100 $\mathrm{msec}$ で出現頻度がやや増加し, 以後 $200 \mathrm{msec}$ まで漸 時出現頻度が減少した，著者の観察したこれらの頭皮上 誘発電位は, Spreng ら ${ }^{11)}$, Schmidt ${ }^{12)}$, および Chatrian $ら^{13)}$ ，佐野 ${ }^{14)}$ の報告している電位変動の一部に相当する と思われるが，Chatrian ら ら $^{13)}$ の報告とはかなり相違す る点が認められた。Chatrian ら ${ }^{13)}$ は坐位の被験者の後 頭部を不関電極として双極誘導しているため, 痛みに対 する運動系の反射的興离に起因する電位変動を記録して いる危険性が大きいと考元られる。

動物の歯に電気刺激を与兄，大脳皮質誘発電位を記録 した報告としては, Hassel $5^{15)}$, Vyklicky $5^{16)}$, Shigenaga $5^{17)}$, Keller $5^{18)}$, 堀田 ${ }^{19}$ のものがあり, Hassel ら ${ }^{15)}$ は $22 \mathrm{msec}$, Vyklicky $ら^{16)} 11.5 \mathrm{msec}$, Shigenaga ら $\left.{ }^{17}\right)$ 7〜11 msec, Keller $ら^{18)}$ は 11〜12 $\mathrm{msec}$, 堀田ら ${ }^{19)}$ は $11 \mathrm{msec}$ といずれも極めて短潜時の 誘発電位を記録しているが，これらは著者が人で観察し た短潜時の要素に対応するものであろら。

\section{3. 歯䯣刺激による頭皮上誘発電位の性質について}

Cracco ら ${ }^{20}$ 怆, 疼痛刺激による誘発電位は筋源性で はないことを報告している。.Chatrian ら ${ }^{8)}$ は，先天性無 痛覚症の患者の歯に電気刺激を加えても誘発電位が得ら れず，正常人被験者の失活歯や，局所麻酔下の歯牙を電 気刺激した場合にも，誘発電位が得られなかったと報告 している，著者の記録した誘発電位は，歯根膜等歯牙周 囲組織の刺激が原因となって起こされた他の感覚による 誘発電位が含まれている可能性を注注否定できるとし ても, 痛覚性のものだけとはいい切れないと考兄, 運動 系の反射的興奮に起因寸ると思われるるのを慎重に検討 した結果, 少なくとも眼球運動に起因するものは認めら れなかった。ささらに頸筋の活動を反影しているのではな いかと思われる電位変化が認められたが，極めて不安定 で，誘発電位とは著しく異なっていた。したがって，誘 発電位は，歯痛情報が大脳皮質で処理される神経性過程 を反映していると考えられる。

\section{4. 針麻酔による痛覚闑値の上昇について}

針麻酔による痛覚間值の上昇については, Anderson
ら 21 は針麻酔による歯の痛覚間值が 1.9 2.2 倍上昇し， さらに針刺した部位に，針の代わりに約 $2 \mathrm{~cm}^{2}$ の表面 電極を置き， $0.3 \mathrm{msec}$ 矩形波で刺激を行って，電の痛 覚闘值の $2.1 \sim 2.4$ 倍の上昇が認められ，この痛覚閾値 の上昇は被験者の被暗示性の大小とは関係ないと報告し ている，Man ら ${ }^{22)}$ は，大腿皮简に種々の刺激を与え， 針麻酔の影響を観察しているが，被験者40名中37例に痛 覚間值の上昇を，4例に振動に対する感覚のわずかな減 少がみられたと報告している。本実験でも，針麻酔によ り, 刺激歯牙の痛覚間值が $1.2 \sim 6$ 倍上昇し, 自覚的に も針麻酔が有効であることが認められた。

\section{5. 針麻酔の頭皮上誘発電位に対する影響}

大浜 $5^{23)}$ ，䮐 $5^{24)}$ ，清水 $5^{25)}$ は，誘発脳波の速い成分 は抑制を受けると報告している。 また，大浜ら ${ }^{23)} は$ 遅い 成分 (80〜120 msec) の振幅は增加したと報告している が，これらの報告は，四肢を刺激しているので方法に問 題がありすぎると思われる.

著者の実験では，記録した誘発電位に対して，抑制の 頻度は，160１80 msec の誘発電位は，必ずある程度の 抑制を受けたが，他の潜時のものは72〜93\%の頻度で抑 制され各潜時間に大差は認められなかった。一方，抑制 の程度も，いずれの潜時の誘発電位でも，66〜85\%で， ほぼ同様の結果を示した。したがって針麻酔が，抑制の 発現頻度, 抑制の程度ともに誘発電位の特定の要素に対 して有効であるといら結果は得られなかった。

疼痛刺激による誘発電位の頂点潜時は報告者によって 大きな差があり，どの要素が痛みによる誘発電位かは依 然不明瞙である。動物では大脳皮質の歯痛の投射は弱 く，また，痛みには特殊な中枢の局在はないともいわれ ている.また, 痛覚の発現には大脳皮質は, 大きな役割は もたないであるらとも考学られている26. 堀田ら ${ }^{19}$ は, ネコの歯髄電気刺激に対する三叉神経脊喵路核から得ら れる誘発電位は，針麻酔に上り数10パーセントの振幅抑 制を受ける。乙かし，大脳皮質誘発電位に対する影響 は，三叉神経核のものに比べると非常に不安定で，しか も効果が少ないと報告している.

しかし，本実験で得られた結果より，自覚的疼痛間值 の上昇とともに, 誘発電位が消失，あるいは振幅の抑制 を受けた事実は，針麻醉が皮質レベルに対しても，不安 定ではあるが，ある程度の作用を有していることが示さ れた。 また同時に，針麻䣷の効果を客観的に定量化する ための指標として誘発電位が有用なことを示した。

\section{V. 結語}

著者は，歯髄の電気刺激により，頭皮上誘発電位を得 ることができれば，痛みに対する針麻酔の効果を客観的 に定量化するための便利な指標になるであるうと検索し た.

1）歯の電気刺激によって，被験者 36 名 99 試行に頭皮 
上誘発電位が得られた。 これに対して，次の点について 検討を加えた。

i）刺激電極の 固定方法を工夫し，電流滑走を最少 限にした。

ii）無䯣歯と，局所麻醉を施した有髄崡を用いて誘 発電位が崡㭪道刺激によるすのであることを確認した.

iii）歯の痛みによる, 眼球運動图, 頸部や後頭部の 筋の放電またはをれらの収縮による䉓極の動摇による 可能性は否定し得た.

2) 得られた頭皮上誘発電位は歯䯣刺激によると思わ れる結論を得た。

3）針麻醉により頭皮上誘発電位が抑制される場合に は，自覚的な痛覚閜値の上昇とよく平行した。

4）針麻醉による頭皮上誘発電位に対する抑制の程度 および頻度は, 誘発電位の潜時とは特定の相関を示さな かった。

5）頭皮上誘発電位は，針麻酔効果の客観的指標に用 いらる.

6) 針麻酔による鎮痛効果はある程度期待でき，今後 の針麻醉の 作用機序の 解明および 臨床応用が 期待され る.

稿を終わるにあたり，終始御舁切な御指尊と御校閱を 頂きました河合幹教授ならびに本学生理学教室佐藤豊彦 教授に深謝いたします。また本実験に多大な御協力を頂 いた北山誠二講師, 堀田文雄学兄ならびに第 2 口腔外科 学教室員各位扰よび本学生理学教室員各位に深謝致しま す.

な扰，本研究の一部は，昭和 49 年 4 月第28回日本口腔 科学会総会，昭和 49 年11月第 4 回日本脳波筋䉓図学衡大 会, 昭和50年 9 月第20回日本口腔外科学会総会, および 臨床脳波誌27)発表した。また，本研究の一部は，昭和 50 年度文部省科学研究費補助金 (奖励研究), 昭和 50 年 . 51 年度厚生省医療研究補助金によったものであることを 付記する。

\section{文献}

1）小田代政美，他：ハリ麻酸について。柾医事 新報 2503 号 : 431972 .

2) Diamond, G.E.: Acupuncture Anesthesia. JAMA 218: 15581971.

3）藤本 洋, 他：針麻醉の口腔外科項域における 応用 (第 2 報). 日口外誌 20：605 1974 .

4）北山誠二, 他: 三叉神経痛に対する針刺通䉓療 法. 日只外誌 20: 1871974.

5) Jasper H.H.: The 10-20 electrode system of the international Fediration. EEG 10: 321 1952.

6) Silverman: 7）大能辉雄より引用.
7) 大能輝雄編：臨床脳波学. 医学書院, 東京, 1963, 41頁.

8) Chatrian, G.E., Farrell, D.F., Canfield, R. C.: Congenital Insensitivity to Noxious Stimuli. Arch Neurol 32: 1411975.

9) Matthews, B. and Searle, B.N.: Electrical Stimulation of Teeth. Pain 2: 2451976.

10) Mumford, J.M. and Newton, A.V.: Zone of excitation when electrically stimulating human teeth. Archs Oral Biol: 13831969.

11) Spreng, M. and Ichioka, M.: Langsame Rindenpotentiale bei Schmerzreizung am Menschen. Pflugers Arch 279: 1211964.

12) Schmidt, J.: Die Beeinflussung der langsamen Hirnrindenpotentiale des Menschen nach elektrischer Zahnreizung durch Analgetika. Acta biol. med. germ. Band 24: 3691970.

13) Chatrian, G.E., Canfield, R.C., Knauss, T.A. and Ettorelettich, R.E.: Carebral responses to electrical tooth pulp stimulation in man. Neurology 25: 7451975.

14）佐野晴男：㐘牙䉓気刺激化上る体性感觉誘発䉓 位に及ぼす刺激強度と $30 \%$ 笑気吸入々の影篦に ついて。 日菌麻誌 5:91977.

15) Van Hassel, H.J., Biedenbach, M.A. and Brown, A.C.: Cortical potentials evoked by tooth pulp stimulation in rhesus monkeys. Archs Oral Biol 17: 10591972.

16) Vyklicky, L., Keller, O., Brozlk, O. and Butkhuzi, S. M. : Cortical potentials evoked by stimulation of tooth pulp afferents in the cat. Brain Research 41: 2111972.

17) Shigenaga, Y., Matano S., Kusuyama, M and Sakai, A. : Cortical neurons responding to electrical stimulation of the rat's incisor pulp. Brain Research 67: 1531974.

18) Keller, O., Butkhuzi, S.M., Vyklicky, L. and Brozeh, O. : Cortical responses evoked by stimulation of tooth pulp afferents in the cat. Physiol Bohemoslov 23: 451974.

19）堀田交雄, 他 : 痛覚上行路の誘発電位儿対する 針麻醉の影響。 日科誌 24: 1931975.

20) Cracco, R.Q. and Bickford, R.G.: Somatomotor and Somatosensory Evoked Responses. Arch Neurol 18: 521968.

21) Anderson, S.A., Ericson, T., Holmgren, E. and Lindqvist. G. : Electro acupuncture: Effect on pain threshold measured with electrical stimulation of teeth. Brain Research 63: 3931973.

22) Man, S.C. and Baragar, F.D. : Local skin sensory changes after acupuncture. CMA J 109: 6091973.

23）大浜和憲, 他：ハリ麻醉とヒトの脳・背噵・末 梢神経・筋レベルに於ける体性知覚譑発電位. 
麻酔 23: 9561974.

24）㰌直矢, 他：体性知覚誘発電位々針麻酔。臨 床脳波 16: 4321974.

25）清水裕幸，他：ハリ麻酔と体性知覚誘発電位. 臨床脳波 18：391 1976.
26) Zimmermann M.: Neurophsiology of Nociception. Nerurophsiology 210: 1791976.

27) 藤本 洋, 他: 幽の䉓気刺激による頭皮上誘発 電位とハリ麻酷。臨休脳波 18: 3991976. 